\title{
RESEARCH NOTE \\ Determination of harvest maturity of D'Agen plums using the chlorophyll absorbance index
}

\author{
Rodrigo Infante ${ }^{1}$, Pía Rubio ${ }^{1}$, Loreto Contador ${ }^{1}$, Massimo Noferini $^{2}$, and \\ Guglielmo Costa ${ }^{2}$ \\ 'Departamento de Producción Agrícola, Facultad de Ciencias Agronómicas, Universidad de Chile, Casilla \\ 1004, Santiago, Chile. \\ ${ }^{2}$ Department of Fruit Trees and Woody Plant Science, Alma mater Studiorum, University of Bologna, 40127 \\ Bologna, Italy.
}

\begin{abstract}
R. Infante, P. Rubio, L. Contador, M. Noferini, and G. Costa. 2011. Determination of harvest maturity of D'Agen plums using the chlorophyll absorbance index. Cien. Inv. Agr. 38(2): 199-203. The objective determination of the optimal harvest date for plums intended either for industrial processing or for consumption as fresh fruit is a fundamental concern of the fruit industry. A portable visible/near infrared (Vis/NIR) spectroscopic device was used to sort D'Agen plums harvested around the traditional commercial harvest date. The chlorophyll absorbance index was found to be capable of segregating plums into classes of maturity according to various concentrations of soluble solids and fruit compression strenght values. Fruits with a chlorophyll absorbance index value of less than 1.59 showed no differences in flesh firmness. Plums harvested with chlorophyll absorbance index values of 1.20-1.29 had a fruit compression strenght of $1.25 \mathrm{~N}$ and a soluble solids concentration of $23.3 \%$. Both of these values correspond to adequate thresholds for harvesting plums for industrial purposes. The chlorophyll absorbance index may be valuable in allowing the identification of high-quality plums either for fresh consumption or industrial processing.
\end{abstract}

Key words: European plum, harvest, maturity, Vis/NIR.

\section{Introduction}

The search for an objective, easy, reliable, and simple index for determining maturity has been investigated by many horticulturists specializing in stone fruits. Any index used by producers, handlers, and quality control personnel must be simple, should be readily used in the field or at the inspection point, and should require relatively inexpensive equipment. The index should be objective (a measurement) rather

Received 14 October 2009. Accepted 11 January 2010. Corresponding author: rinfante@uchile.cl than subjective (an evaluation), and, ideally, the measurement process should be non-destructive (Crisosto, 1994).

European plums (Prunus domestica L.) are climacteric fruits in which the chlorophyll content decreases during ripening (Crisosto, 1994), and the measurement of this change is an unequivocal indication of maturation. European plums are used mainly for processing into prunes (Ertekin et al., 2006) and for fresh consumption; thus, the traditional indices used to determine the optimal harvest date are the soluble solids concentration (SSC) and the flesh's firmness (Crisosto and Mitchell, 2002). 
A portable system of visible near infrared (Vis/ NIR) spectroscopy system was developed recently. This instrument provides fast and reliable data on the internal properties of many fruit species (Ziosi et al., 2008) by measuring the difference in absorbance between two wavelengths $(670$ and $720 \mathrm{~nm}$ ) close to the peak of chlorophyll $a$. In this study, a portable Vis/NIR device was used to characterize the harvest maturity of D'Agen plums as a way to establish the use of the chlorophyll absorbance index $\left(\mathrm{I}_{\mathrm{AD}}\right)$ for determining the time of harvest for this fruit variety.

\section{Materials and methods}

D'Agen plums (French prunes) were obtained from a commercial orchard located near Santiago, Chile. Twelve trees were used in this trial, and plums from these trees were harvested daily during February 2009. A total of 900 plums were harvested during a three-week span, beginning two weeks before and ending one week after the traditional commercial harvest date used by the local plum industry. The plums were analyzed individually and non-destructively with a DA meter, which is a portable Vis/NIR instrument (Sinteleia, Bologna, Italy), to determine the $\mathrm{I}_{\mathrm{AD}}$. The DA meter is an instrument that uses the absorbency properties of chlorophyll to measure the chlorophyll content in the fruit's skin. The chlorophyll content of a fruit is a precise index of a fruit's ripeness. The peach is a climacteric fruit that exhibits decreasing chlorophyll content during ripening (Chalmers and van den Ende, 1975), and the difference in absorbance between two wavelengths near the chlorophyll a peak (the index of absorbance difference, $\mathrm{I}_{\mathrm{AD}}$ ) is related to the actual chlorophyll content in the fruit's skin and is, therefore, related to the physiological processes of fruit maturation. For each fruit, the average of three measurements obtained from the cheeks was determined for further data analysis.

After Vis/NIR analysis, the compression strenght of the flesh was evaluated non-destructively by inserting a $21 \mathrm{~mm}$ diameter plunger supported by an electronic fruit texture analyzer (Guss, Strand, South Africa) into the cheek of intact plum to a depth of $1 \mathrm{~mm}$. The firmness of the flesh of single plums was measured after skin removal with the same fruit texture analyzer, but employing a $7.9 \mathrm{~mm}$ plunger. The SSC was also measured for each plum using a digital ATC-1E refractometer (Atago, Tokyo, Japan).

Once the instrumental measurements were completed, all of the data regarding the plums and their time of harvest were grouped into six classes of $\mathrm{I}_{\mathrm{AD}}$ values $(1.20-1.29 ; 1.30-1.39 ; 1.40$ $1.49 ; 1.50-1.59 ; 1.60-1.69$ and $1.70-1.79)$, which represented $95 \%$ of all of the harvested fruits. Following ANOVA, significant differences between the means were determined by Duncan's separation test $(\mathrm{P} \leq 0.05)$ (García-Villalpando et al., 2001).

\section{Results and discussion}

The plums collected during the period around the traditional commercial harvest date showed $\mathrm{I}_{\mathrm{AD}}$ values that varied between 1.87 at the first harvest and 0.13 at the last harvest. Despite this wide range, $95 \%$ of all of the harvested plums had $\mathrm{I}_{\mathrm{AD}}$ values of between 1.20 and 1.79 (Figure 1). As peaches, plums and nectarines ripen, substantial physical changes occur in their skin color (Iglesias and Echeverría, 2009). The fruit color is determined by the various pigments present in the skin and the flesh of the fruit (Stembridge et al., 1972), and, normally, the color changes from green, associated with elevated chlorophyll content, to red, yellow or deep blue (Crisosto, 1994). D’Agen plums were sorted into six $\mathrm{I}_{\mathrm{AD}}$ classes; the 1.70-1.79 class (n $=45$ ) had the lowest number of plums, and the $1.50-1.59$ class $(n=260)$ had the most plums.

The $\mathrm{I}_{\mathrm{AD}}$ class with the lowest values (1.20-1.29) contained the plums with the highest SSCs, while the $\mathrm{I}_{\mathrm{AD}}$ class with the greatest values (1.70-1.79) contained the plums with the lowest SSC values; the 1.40-1.49 $\mathrm{I}_{\mathrm{AD}}$ class, which represented the mean $\mathrm{I}_{\mathrm{AD}}$, contained plums with the mean SSC value. The 1.50-1.59, 1.60-1.69 and 1.70-1.79 classes showed no differences among one another (Table 1). Complete separation of the means of the flesh-firmness values for each of the six treatments or $\mathrm{I}_{\mathrm{AD}}$ classes was not ob- 


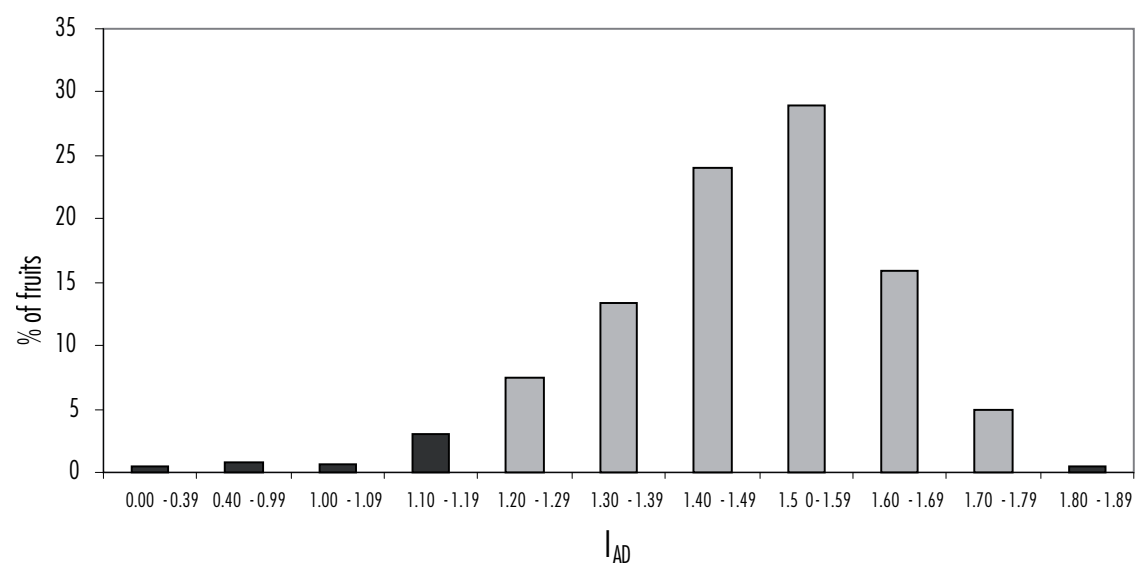

Figure 1. Percentages of D'Agen plums $(n=900)$ sorted into classes based on $I_{A D}$ (visible near infrared spectroscopy) values. Gray bars indicate the ranges used for data analysis, which represent $95 \%$ of the total data.

served. The DA meter segregated only the class that ranged from 1.70 to 1.79 from the class that ranged from 1.60 to 1.69 , while all of the other classes were grouped together and exhibited no differences. However, these four classes showed relatively small differences with respect to flesh firmness: between the highest and lowest classes, a difference of only $1.9 \mathrm{~N}$ was observed, which is an insignificant difference from a practical perspective (Table 1). In contrast, fruit compression strenght, though not a common index used by the plum industry, showed an association with $\mathrm{I}_{\mathrm{AD}}$ (Table 1). According to Usenik et al. (2008), the cultivar has a significant influence on fruit weight, SSC, firmness, total acid content, total phenols and anthocyanins in European plums. Ripening resulted in increased fruit weight and SSC and decreased flesh firmness and total acid content.
Other authors have used the $\mathrm{I}_{\mathrm{AD}}$ and have established different classes of ripeness; Ziosi et al. (2008) implemented three classes for Stark Red Gold nectarines. The various classes showed significant differences with respect to SSC, firmness and acidity with $\mathrm{I}_{\mathrm{AD}}$ values ranging from 0.3 to 1.2. Costa et al. (2008) established two classes for Fayette peaches and found differences in ethylene production, firmness and acidity associated with $\mathrm{I}_{\mathrm{AD}}$.

The results observed in this study show that $\mathrm{I}_{\mathrm{AD}}$ values can be used to sort plums into groups with various SSC and fruit compression strenght values for at least three classes of $\mathrm{I}_{\mathrm{AD}}$. Class $1.70-1.79$ primarily contained plums in a state of incipient maturity, suggesting that these plums are most appropriate for the fresh market, while class 1.20-1.29 contained ripe to over-

Table 1. Soluble solids concentration (SSC), flesh firmness and fruit compression strenght evaluated in D'Agen plums that were sorted into six classes according to their $\mathrm{I}_{\mathrm{AD}}$ values.

\begin{tabular}{cccc}
\hline $\mathrm{I}_{\mathrm{AD}}$ class & SSC (\%) & Firmness (N) & Compression strenght (N) \\
\hline $1.20-1.29$ & $23.27 \mathrm{~d}$ & $24.2 \mathrm{a}$ & $12.2 \mathrm{a}$ \\
$1.30-1.39$ & $22.94 \mathrm{~cd}$ & $25.1 \mathrm{a}$ & $12.5 \mathrm{ab}$ \\
$1.40-1.49$ & $22.45 \mathrm{bc}$ & $25.6 \mathrm{a}$ & $12.9 \mathrm{ab}$ \\
$1.50-1.59$ & $21.86 \mathrm{ab}$ & $26.1 \mathrm{a}$ & $13.1 \mathrm{bc}$ \\
$1.60-1.69$ & $21.48 \mathrm{a}$ & $28.9 \mathrm{~b}$ & $13.7 \mathrm{c}$ \\
$1.70-1.79$ & $21.29 \mathrm{a}$ & $32.3 \mathrm{c}$ & $14.2 \mathrm{~d}$ \\
\hline
\end{tabular}

Different letters between columns indicate significant differences $(\mathrm{P} \leq 0.05)$. 
ripe plums with $1.25 \mathrm{~N}$ compression strenght, $25.5 \mathrm{~N}$ firmness and 23.3\% SSC, levels that are more appropriate for processing purposes. Any increase in SSC values beyond this point is ascribable exclusively to fruit dehydration, rather than sugar accumulation (Krueger and Wilbur, 2006). Plums in the 1.20-1.29 class with elevated SSC values are the ideal raw material for obtaining high-quality dried products (Dejong et al., 2002). Few studies have been published regarding the best maturity level (in terms of SSC or flesh-firmness values) for the consumption of fresh European plums that could guarantee a high-quality product.
The results obtained in this study could initiate the development of $\mathrm{I}_{\mathrm{AD}}$ as a harvest index for plums, particularly when the product is intended for the fresh fruit market. In the future, the association between $\mathrm{I}_{\mathrm{AD}}$ values and other physiological traits, such as respiration and ethylene production, will also be studied.

\section{Acknowledgments}

The authors would like to thank the CORFOINNOVA VI Region Research Project on Prunus Breeding for supporting this research.

\title{
Resumen
}

\begin{abstract}
R. Infante, P. Rubio, L. Contador, M. Noferini y G. Costa. 2011. Determinación de la madurez de cosecha en la ciruela D’Agen a través del índice de absorción de clorofila.
\end{abstract} Cien. Inv. Agr. 38(2): 199-203. La determinación objetiva del momento óptimo de cosecha de las ciruelas europeas, destinadas tanto para el consumo en fresco y la agroindustria, es una preocupación fundamental para la industria frutícola. Se utilizó un dispositivo espectroscópico Vis/NIR para la clasificación de ciruelas D'Agen cosechadas en torno a la fecha de cosecha comúnmente usada por la industria local. El índice de absorción de clorofila demostró ser capaz de separar los sólidos solubles y la fuerza de compresión de la fruta en las diferentes clases de madurez. La fruta clasificada con un índice de absorbancia de la clorofila menor a 1,59 no mostró diferencias en la firmeza de la pulpa. Las ciruelas cosechadas con un índice de absorbancia de la clorofila entre 1,20-1,29 presentaron una fuerza de compresión de 1,25 N y $23,3 \%$ de concentración de sólidos solubles, siendo estos valores umbrales adecuados para la cosecha de ciruelas para fines industriales. El índice de absorción de la clorofila representa un valioso índice que permitiría obtener ciruelas de alta calidad tanto para el consumo en fresco o procesamiento industrial.

Palabras clave: Ciruela europea, madurez de cosecha, Vis/NIR.

\section{References}

Chalmers, D.J., and B. van der Ende. 1975. A reappraisal of the growth and development of peach fruit. Journal of Plant Physiology 2:623-634.

Costa, G., G. Fiori, M. Mennone, G. Noferini, and V. Ziosi. 2008. Sviluppo di metodi innovativi di gestione dei frutti nella fase di post-raccolta: definizione degli indici di raccolta in funzione della qualità di conservazione e di commercializzazione.In: VI convengo nazionale sulla peschicoltura meridionale, 6-7 March 2008, Caserta, Italia. p. 349-353.
Crisosto, C. 1994. Stone fruit maturity indices: a descriptive review. Postharvest news Info 6: 65-68.

Crisosto, C., and F. Mitchell. 2002. Postharvest handling systems: Stone fruits. Peach, nectarine and plum. In: Kader, A. (ed.). Postharvest Technology of Horticultural Crops. University of California Agriculture and Natural Resource, California, USA. p. 345-350.

Dejong, T.M., J.F. Doyle, and C.J. Debuse. 2002. Development of a Prune Breeding Program in California. Acta Horticulturae 577:151-153.

Ertekin, C., S. Gozlekci, O. Kabas, S. Sonmez, and I. Akinci. 2006. Some physical, pomological and 
nutritional properties of two plum (Prunus domestica L.) cultivars. Journal of Food Engineering 75: 508-514.

García-Villalpando, J.A., A. Castillo-Morales, M.E. Ramírez-Guzmán, G. Rendón-Sánchez, and M.U. Larqué-Saavedra. 2001. A comparison of Tukey, Duncan, Dunnet, HSU and Bechhofer procedures for selection of means. Agrociencia 35: 79-86.

Iglesias, I., and G. Echeverría. 2009. Differential effect of cultivar and Harvest date on nectarine colour, quality and consumer acceptance. Scientia Horticulturae 120: 41-50.

Krueger, B., and R. Wilbur. 2006. Prune harvest timing. Sacramento Valley prune newsletter. July
2006. Fruit and Nut Notes. Cooperative Extension University of California, Davis, CA.

Stembridge, G.E, R.A. Baumgardner, W.E. Johnston, and L.O. Van Blaricom. 1972. Measuring uniformity of peach maturity. HortScience 7: 387-389.

Usenik, V, D. Kastelec, R. Veberic, and F. Stampar. 2008. Quality changes during ripening of plums (Prunus domestica L.). Food Chemistry 111: 830-836.

Ziosi, V., M. Noferini, G. Fiori, L. Tadiello, L. Trainotti, G. Casadoro, and G. Costa. 2008. A new index based on vis spectroscopy to characterize the progression of ripening in peach fruit. Postharvest Biology and Technology 49: 319-329. 
